\title{
Movement-relevant Theory: Rethinking Social Movement Scholarship and Activism
}

\author{
DOUGLAS BEVINGTON* \& CHRIS DIXON** \\ *Department of Sociology, University of California, USA, **History of Consciousness Department, University
} of California, USA

\begin{abstract}
The dominant American social movement scholarship has become detached from the concerns of actual social movements. But the dramatic growth of social movement activity in recent years, especially the global justice movement, is creating the conditions for an emerging new direction in social movement scholarship which prioritizes the relevance of such work to the movements themselves. A problem in the current social movement literature is that the different schools of thought tend to overemphasize particular variables and pit them against one another. Rather than simply seeking to emphasize a different variable in the lifecycle of a social movement, a movement-relevant approach has the potential to transcend these schisms (such as structure versus culture). At the same time, this approach does not categorically reject earlier theoretical perspectives, but instead seeks to glean what is most useful for movements from these earlier works. Likewise, this emergent direction entails a dynamic engagement with the research and theorizing already being done by movement participants. In this paper, we explore this growing convergence of movement-relevant scholarship, identifying the academic work being used by movement participants as well as the analysis taking place within the movements themselves, with a particular focus on the global justice movement.
\end{abstract}

KEY Words: Social movement theory, activism, relevance, political process theory, antiglobalization movement, global justice movement

It is surprising how much discipline is imposed upon theory by requiring that it 'make a difference' and provide guidance or useful illumination. I learned long ago from students in professional schools that questions of 'so what' or 'what relevance does this have' do not signify impatience with theory per se, much less antiintellectualism, but only impatience with the obvious, general, remote, and vague statements that often parade as social science theory. One test of good theory is that it have practical implications. (Charles Perrow, 1970, p. vii)

\section{Introduction}

Social movement theory in the USA is in a quagmire. Political process theory ${ }^{1}$ (PPT) has been the dominant social movement theory for nearly two decades and continues to hold a strong influence over how scholars discuss and research movements. Yet in recent years,

Correspondence Address: Douglas Bevington, Department of Sociology, 235 College 8, University of California, Santa Cruz, Santa Cruz, CA 95064, USA. Tel.: + 1 (831) 423-5403; Email: dougbev@ucsc.edu

1474-2837 Print/1474-2829 Online/05/030185-24 (C) 2005 Taylor \& Francis

DOI: $10.1080 / 14742830500329838$ 
PPT has come under criticism both from scholars outside of that tradition and even some of its main proponents. Neither, however, offers a satisfying alternative to the dominant approach, at least one that retains a hearty role for theory, including large-scale theory.

Moreover, these critiques have missed a central problem with the dominant social movement theory: it is not being read by the very movements that it seeks to illuminate. The reason for this, we contend, is that activists do not find such theory useful. This is not to say that they are not interested in social movement studies or social movement theory. Activists are reading academic social movement histories. But rather than reading the dominant social movement theory, they are generating theory largely outside of academic circles. This is important and valuable. Yet we also want to argue for the value of academic social movement theory that is useful to movements. Thus, at a time when academics are retreating from a vital role for social movement theory, we seek to explore an alternative approach: movement-relevant theory.

In this paper we look to chart this emerging direction for social movement scholarship. We begin with a review of the main critiques of PPT. We then bring in Richard Flacks' alternative critique to introduce the neglected issue of relevance. From there we develop the concept of a movement-relevant approach to theory that puts the needs of social movements at its heart. We show that movements themselves generate such theory, using the global justice movement ${ }^{2}$ as a chief example. Taking guidance from this work, we propose a methodology for producing academic scholarship that is similarly useful to movements. We then seek to recover an overlooked legacy of movement-relevant theory within academic scholarship. Finally, we point to the resurgence of social movement activity in recent years as constituting especially promising conditions for the growth of a movement-relevant approach.

Our perspective grows out of our own engagements with movements in North America. In our involvements in environmental, global justice, anti-war, and other kinds of activism, we have seen the vibrancy of internal movement discussions and production of theory. In our involvement in academia, we have seen the potential of theory that is useful and accountable to movements. What is particularly striking to us then is that, by and large, social movement studies - precisely the venue where one would expect greatest utility for movements - has not manifested this potential. We thus approach this work with a persistent hope that the vibrancy and relevance of movement-generated theory can be recognized and inform the study of social movements and, in turn, that the resources and tools of social movement studies can inform and assist movements.

To be clear, this paper focuses specifically on the status of American social movement theory and its relation to movements in the USA. We do not seek to make claims about the relations between social movement theory and movements outside of the USA, where there may well not be the same level or form of disjuncture between social movement scholarship and activism. ${ }^{3}$

\section{The Critique of Political Process Theory}

After almost twenty years as the dominant social movement theory in the USA, PPT is facing growing criticism. Perhaps the most notable critique is Jeff Goodwin and James Jasper's article 'Caught in a winding, snarling vine' in Sociological Forum's 1999 minisymposium on social movements. A fundamental problem with PPT, they contend, is its tendency to 'overextend' key concepts, like political opportunity and mobilizing structure, 
so far as to become tautological and analytically useless. In the context of PPT, 'virtually anything that, in retrospect, can be seen as having helped a movement mobilize or attain its goals becomes labeled a political opportunity' (Goodwin \& Jasper, 1999a, p. 36).

Goodwin and Jasper also target what they call PPT's 'structural bias'. In the case of political opportunities, for example, PPT places emphasis on structural 'openings' that lead to mobilization rather than the process by which movement activists come to perceive opportunities. Yet 'There may be no such thing as objective political opportunities before or beneath interpretation - or at least none that matter; they are all interpreted through cultural filters' (Goodwin \& Jasper, 1999a, p. 33). As Jasper notes elsewhere, 'The term structure misleadingly implies relatively fixed entities, so that attention is often diverted away from open-ended strategic interplay' (Jasper, 1997, p. 36). In fact, Goodwin and Jasper claim, cultural and strategic processes are always implicated in structures.

Goodwin and Jasper have thus provided the most detailed and influential critique of PPT to date. But the vigor of their critique of contemporary social movement theory has led some scholars to view their work as anti-theory. In the Sociological Forum symposium, David Meyer contends that 'Godwin and Jasper ask us to back away from larger theoretical concerns and ambitions and simply explain particular cases' (Meyer, 1999, p. 87). 'Such desperate resignation', he remarks, 'seems to me to be contrary to the very spirit of social science' (Meyer, 1999, p. 84). Likewise, Charles Tilly concludes that under Goodwin and Jasper's line of reasoning, 'analysts can seek only to describe and explain particular instances of contentious politics' (Tilly, 1999, p. 58). Goodwin and Jasper deny the charge that their approach allows only for descriptive case studies (Goodwin \& Jasper, 1999 b, p. 108). Regardless of whether this criticism is warranted, their work presents a notably more limited role for social movement theory. As they state, 'We ourselves favor causal explanations based on small-scale mechanisms and middle-range theories over explanations with pretensions to universality' (Goodwin \& Jasper, 1999b, p. 107).

In addition, Goodwin and Jasper make clear that they 'are not (and will never be) advocates of any alternative paradigm [of social movement theory], as that concept is generally understood' (Goodwin \& Jasper, 1999b, p. 108).

Such reluctance is understandable. In The Art of Moral Protest, Jasper meticulously documents how not only PPT but also other schools of social movement theory have frequently overextended their use of key analytical categories to such an extent as to deprive them of any real meaning in understanding social movement behavior. It is not surprising, then, that Goodwin and Jasper are reluctant to avoid proposing a new paradigm out of concern that it would recapitulate this tendency towards overextension. But that still leaves us in the quagmire. While providing a sophisticated critique of PPT, Goodwin and Jasper falter at the point offering a path beyond it, at least one that includes a hearty and vibrant role for theory.

\section{The Response within Political Process Theory}

While Goodwin and Jasper avoid proposing a new paradigm, their critique of PPT has been very influential. Principal figures in the development of PPT are now distancing themselves from PPT and attempting to construct a revised path for social movement theory.

Doug McAdam (1999), who first formulated PPT, echoes and elaborates upon many of Goodwin and Jasper's criticisms in the introduction to the second edition of Political 
Process and the Development of Black Insurgency, 1930-1970. He claims guarded sympathy with their critique of 'structural bias' and offers his own critical remarks on the 'structural determinism' so often embedded in both political opportunity structures and mobilizing structures (McAdam, 1999, pp. xxxii, xi-xii). He additionally argues for a far more dynamic approach to studying movements. And most broadly, he proposes an ambitious project of synthesis: 'Unless we combine structuralist, culturalist and rationalist tenets with insights gained from the study of other forms of contention, we cannot hope to develop anything close to a complete understanding of the origins of movements' (McAdam, 1999, p. xxxvii).

McAdam's revised approach receives fuller articulation through collaboration with Sidney Tarrow and Charles Tilly in Dynamics of Contention (2001). This book marks what they undoubtedly see as a substantial break from their previous work - the "classic social movement agenda' as they now refer back to it - and its shortcomings. They argue stridently, 'the static, individualistic, and often reified character of previous analyses including our own - bars the door to dynamic, interactive analyses of mobilization and demobilization' (McAdam et al., 2001, p. 73). In a fascinating turn of events, then, PPT has fallen into disfavor even among some of its longtime champions.

In an effort to create a more 'relational' and 'dynamic' approach, McAdam, Tarrow, and Tilly suggest an expanded scope of analysis into 'contentious politics'. For them, this means situating social movements alongside industrial conflicts, wars, interest group politics, nationalism, and democratization, among others. Their search throughout is 'for causal analogies: identification of similar causes in ostensibly separate times, places, and forms of contention' (McAdam et al., 2001, p. 74).

No longer looking for 'general laws of contention', McAdam, Tarrow, and Tilly now seek to find 'mechanisms' that combine into recurrent 'processes', which, in turn, constitute 'episodes' of contention (McAdam et al., 2001, pp. 313-314). Looking at the episode of the May 1968 general strike in France, for instance, they identify the mechanisms of diffusion ('the transfer of information along established lines of interaction'), attribution of similarity ('the mutual identification of actors in different sites as being sufficiently similar to justify common action'), and emulation ('collective action modeled on the action of others') (McAdam et al., 2001, pp. 333-335). Together, they argue, these constitute the process of scale shift in which localized confrontations between university students and administrators sparked revolts across the country.

McAdam, Tarrow, and Tilly's focus is decidedly constricted. Their aim is to attend 'less to differences in the forms and outcomes of contention than to the dynamic mechanisms and processes that they seem to share in common' (McAdam et al., 2001, p. 123). In other words, the particular movements that erupted in Paris and the outcomes of the strike interest them much less than the comparability to, say, the Rwandan genocide of 1994, which, they contend, is also an example of scale shift (McAdam et al., 2001, p. 337). This highlights their central concern, which is explicitly about finding and demonstrating welldefined causal connections that can encompass dynamism, interdependence, and contingency.

McAdam, Tarrow, and Tilly thus arrive at a surprisingly similar place to Goodwin and Jasper. While focusing so attentively on mechanisms and processes, they eschew any role for theory beyond drawing parallels between narrow causal relationships in varying circumstances. They themselves emphasize 'resistance to the seductions of general laws and general models: how the ideal social movement works, how the ideal revolution 
works, and so on' (McAdam et al., 2001, p. 190). Consequently, while they attempt to offer an alternative to the shortcomings of PPT, in doing so they notably truncate the theoretical dimensions of such work. If we are to locate a new direction for social movement theory that includes a truly dynamic space for theory, especially large-scale theory, then we must again look elsewhere.

\section{Movement-relevant Theory}

Richard Flacks has offered an alternative critique of contemporary social movement scholarship that resituates theory but does not abandon it. He introduces a crucial dimension to the discussion: relevance. ${ }^{4} \mathrm{He}$ notes the growth of contemporary social movement theory as evidenced by 'the plethora of research compilations, annuals, journals, and advanced textbooks dealing with social movements'. But in the face of this abundance, he asks: 'What is all this analysis for? In what way does the validation, elaboration, and refinement of concepts provide useable knowledge for those seeking social change?' (Flacks, 2004, p. 138).

Flacks contends that contemporary American social movement theory, especially PPT, is largely irrelevant to social movement participants. Our experiences with North American movements support Flacks' assessment. In our own research and participation in the environmental, global justice, and anti-war movements, we have found that these activists are not choosing to read the dominant contemporary social movement theory, and moreover those activists who have encountered it have generally not found it useful. ${ }^{5}$

What does it say if the social movement theory being produced now is not seen as helpful by those persons who are directly involved in the very processes that this theory is supposed to illuminate? It suggests that the problems with this theory are larger than simply which set of variables is being emphasized. Indeed, the biggest problem with contemporary social movement theory is that it is not particularly relevant to the very movements it studies. While this critique presents a stark picture of the current status of the field, it also points to a promising path away from the current quagmire in social movement theory: movement-relevant theory.

We should clarify that with the term movement-relevant theory we mean to focus specifically on movement-relevant social movement theory, not social movement histories. The latter field does not seem to face the same problems with relevance and is often well received by movement participants (Green, 2000). Likewise, the term is not intended to refer to other fields of scholarship that can and do have relevance to social movements but do not directly research those movements. ${ }^{6}$ Yet, ironically, much of the current theory and research that is most directly focused on social movements is of comparatively little use to those movements. Movement-relevant theory seeks to bridge this divide between social movement scholarship and the movements themselves.

What could this alternative approach to social movement scholarship entail? To explore this path, we should begin by suggesting a preliminary outline of what we mean by movement-relevant theory. It is social movement theory that seeks to provide 'useable knowledge for those seeking social change' (Flacks, 2004, p. 138). It is concerned with producing more than just good case studies and histories of social movements. Instead, it seeks to draw out useful information from a variety of contexts and translate it into a form that is more readily applicable by movements to new situations - i.e. theory. Movement participants can and do produce such theory. Scholars can produce movement-relevant 
theory as well (though at present many aren't) and may even be in a distinctly favorable position to do so.

To produce movement-relevant theory, it is not enough simply to identify with a movement or study a movement. Instead, there is a distinct process that involves dynamic engagement with movements in the formulation, production, refinement, and application of the research. Moreover, the researcher need not and in fact should not have a detached relation to the movement. Rather, the researcher's connection to the movement provides important incentives to produce more accurate information, regardless of whether the researcher is studying a favored movement or its opponents. And while movementrelevant theory is not entirely new, the present moment offers distinct opportunities for it to play a more prominent role in social movement scholarship.

Movement-relevant theory is particularly promising now because it transcends many of the problems highlighted by Jasper in the development of new forms of social movement theory. Movement-relevant theory differs from previous approaches in that it does not seek to privilege a particular variable or set of variables in the lifecourse of a movement. As such it avoids succumbing to the sort of overextension and internecine squabbles that have hindered previous schools. Rather, movement-relevant theory emerges out of a dynamic and reciprocal engagement with the movements themselves. This engagement not only informs the scholarship but also provides an accountability for theory that improves the quality of theory. It imposes what Charles Perrow described in another context as a 'discipline' on theory production:

It is surprising how much discipline is imposed upon theory by requiring that it 'make a difference' and provide guidance or useful illumination. I learned long ago from students in professional schools that questions of 'so what' or 'what relevance does this have' do not signify impatience with theory per se, much less antiintellectualism, but only impatience with the obvious, general, remote, and vague statements that often parade as social science theory. One test of good theory is that it have practical implications. (Perrow, 1970, p. vii)

Richard Flacks mirrors this sentiment in the context of social movement theory, highlighting the contrast between the dominant theories today and a more movementrelevant approach:

to the extent that contemporary movement studies are driven by efforts to refine theoretical concepts they are likely to appear as irrelevant or obvious to organizers. Organizers already know about the need for 'frame alignment', the value of 'informal networks', and the importance of 'opportunity structures'. They would benefit from studies that provide clues about how to accomplish such alignment, how to tap into such networks and how to identify such opportunities. (Flacks, 2004, p. 147)

Movement-relevant theory is both a promising direction for social movement scholarship and an already emerging tendency with a history that requires further exploration. Later in this paper, we will highlight some of the ways in which the conditions for movementrelevant theory have improved and also examine work that is already being done in this vein. But first we will expand on our discussion of movement-relevant theory through further clarification and explanation of key concepts around this approach. 
Movement-relevant Theory

\section{The Value of Theory}

To begin, we should distinguish why we emphasize the term movement-relevant theory rather than relying solely on the general term movement-relevant scholarship. In this paper we are seeking a broad space for theory, including large-scale theory, within social movement scholarship at a time when that space appears to be contracting. And we believe that this expansive vision of the role of theory is relevant to movements. As discussed above, most critics of PPT have sought to step away from large-scale theories in favor of an emphasis on case studies and narrowly defined causal relationships. There is little doubt that social movement histories and case studies can help inform other social movements (Green, 2000). And, indeed, from what we have seen, activists actively seek out these accounts. They offer valuable lessons that can then be translated by activists into their own movements.

At the same time, we feel the need to question whether that focus actually shirks some of social science scholars' responsibilities to movements. Activists are capable of drawing lessons from case studies to apply to their own movements. But should the work of drawing larger lessons from these cases be left to organizers alone? Indeed, the task of examining various social phenomena and then identifying the larger patterns is a reasonable definition of theory. We certainly don't wish to suggest that theory production is the exclusive domain of academics. (As we discuss below, activists can and do generate useful theory on their own.) But social scientists are in a good position to contribute to the production of that theory, both by virtue of their training and by the research time available in the academy. Of course, there is always the danger that social scientists will draw overly broad or universalistic conclusions, clearly a concern of importance to many of the theorists we have discussed. But not to attempt to participate in theory production including the production of large-scale theory - is to deny movements a valuable ally in developing the larger models needed to help situate and inform social movement strategy.

\section{Engagement and Accuracy}

The success of PPT has been intertwined with an effort among those scholars to highlight the credibility of social movement studies as legitimate social science research. In the wake of these professional advances, it might seem troubling to suggest a change in direction for social movement studies that challenges the detachment of the scholar from the movement. For many, no doubt, this separation is seen as a cornerstone of a scientistic approach, the basis for 'objectivity' and unbiased results. To challenge this separation might seem to threaten the quality of the information produced by the research. But we would argue that this is a false choice.

Movement-relevant scholarship should not, and indeed cannot, be uncritical adulation of a favored movement. While a social movement may be grateful for adulation in the short term, such an approach does not provide it with any useful information and does not aid the movement in identifying and addressing problems which may hinder its effectiveness. Likewise, movement-relevant research cannot be an uncritical reiteration of the pre-existing ideas of a favored movement. If the research is exploring questions that have relevance to a given movement, it is in the interests of that movement to get the best available information, even if those findings don't fit expectations. Indeed, some of the most useful research produces results which defy 'common-sense' assumptions; Frances 
Fox Piven and Richard Cloward's (1977) analysis of the ways in which social movement organizations have actually served as a damper on social change is a classic example. To produce results that are biased - intentionally or unconsciously - to favor the assumptions of a particular movement ultimately does that movement a disservice as it will then develop strategies based on faulty premises.

This means that social movement scholars need not and in fact should not aspire to be detached from movements. Instead, the researcher's connection to the movement provides important incentives to produce more 'objective' research to ensure that the researcher is providing those movements with the best possible information. Indeed, the engaged researcher has more of a stake in producing accurate findings than one with no stake in the movement.

This is true whether one studies a movement one supports or a movement one opposes. In the case of the latter, the researcher seeks to provide the opponents of the studied movement with the most accurate possible understanding of that movement. An excellent example of this dynamic can be found in the work of Sara Diamond. While coming from an explicitly left political perspective, Diamond has produced some of the best available studies of the modern Christian Right in the USA. In Not by Politics Alone (1998) she is explicitly critical of the depiction of the Christian Right movements as mere corporate front groups by liberal organizations such as Planned Parenthood and People for the American Way. This caricature is both inaccurate and misleading. If progressives hope to respond effectively to the growth of the Christian Right, they need to begin by understanding the real mass base and appeal of their opponents. Diamond's scholarship, grounded in a commitment to accuracy reinforced by her political commitments, is an important contribution to that goal.

Likewise, researchers connected with conservative institutions, particularly the police and military, generate useful information through studies of progressive movements. One clear indicator of the relevance of such work is that progressive activists are actively seeking out such material. For example, global justice activists are reading analyses of their movement by social scientists working for the Canadian Security Intelligence Service (Canadian Security Intelligence Service, 2000). This engagement by activists with conservative social movement studies was foreshadowed by Marcy Darnovsky, Barbara Epstein, and Richard Flacks in an earlier essay lamenting the detachment of contemporary progressive social movement scholarship: 'One might almost become nostalgic for the time when the sociology of social movements connected directly to the interests of agencies of social control, for at least such connection meant that researchers were dealing with specific movements with some effort at descriptive depth' (Darnovsky et al., 1995b, pp. $x v-x v i)$. The point is that activists take this type of research seriously, despite the affiliations of its authors, because those researchers are taking the movements seriously.

Conservative institutions are producing not only useful studies of movements but dynamic theory as well. For instance, perhaps one of the most interesting scholarly contributions to the study of the global justice movement comes from the RAND Institute, a Defense Department-affiliated think tank. RAND associates John Arquilla and David Ronfeldt's theorization of 'netwar', decentralized forms of conflict involving nontraditional, non-hierarchically networked organizations, first emerged in the mid-1990s (Arquilla \& Ronfeldt, 1996). But their discussion within this theory of the use of 'swarming' tactics by decentralized networks has offered a crucial tool for understanding the success of global justice activists on the streets of Seattle during the 1999 World Trade 
Organization Ministerial. The lessons of the 'Battle of Seattle' have subsequently been incorporated into the development of netwar theory in Networks and Netwars (Arquilla \& Ronfeldt, 2001). The result has been one of the more useful contributions to social movement theory in the USA in recent years. And, again, movement participants are actively reading and engaging with this material. When Networks and Netwars was first released, it was widely circulated among global justice activists. What does it say about the state of social movement theory that these activists are reading the work of RAND researchers more than PPT produced by ostensibly more progressive scholars? ${ }^{7}$

\section{Movements and Theory}

Above, we observed that in both our research and our participation in contemporary social movements we have seen that activists are not reading dominant social movement theory. We have encountered at least two general forms of explanation for this disjuncture. One is critical of activists, arguing that they are either 'anti-intellectual' or that many of them lack the analytical skills or willingness to deal with abstract concepts in order to sufficiently appreciate social movement theory. Yet, as we will argue, activists are deeply engaged with theory, including abstract and rather difficult material.

The other form of explanation is more generous. It seeks to explain the disjuncture in terms of limitations on activists' access. Frequently this is articulated by referring to the 'potential' utility of particular examples of social movement scholarship if only activists were exposed to it. Such an analysis may be accompanied by calls for increased access to these materials. Further, it may be accompanied by calls to make social movement scholarship more accessible by writing in different media and perhaps different tones. But while it is certainly commendable to make scholarship more comprehensible to broader audiences, we do not think that this is the core problem.

Fundamentally, both of these forms of explanation put the onus for the disjuncture on activists. Yet activists are more than willing to engage with academic scholarship. Indeed, useful and relevant ideas get a good deal of circulation among activists even when coming from less accessible sources. Flacks corroborates what we too have experienced:

activists are hungry for insight into the practices and experiences of organizers, into how collective and personal commitment can be sustained, into relationships between day to day activism and 'long-range vision', into problems of intramovement contention, organizational rigidity and democracy, etc. (Flacks, 2004, pp. 146-147)

So it does not appear that the main issue here is either 'anti-intellectualism' or access. Instead, as we have suggested, it seems to be a problem that activists are finding little of use among contemporary social movement scholarship. From this perspective, a focus on 'potential' utility risks distracting attention from the central problem. Rather than asking about how to get activists to read this scholarship, we should be asking how to produce useful information that activists will want to read and seek out on their own. In this regard, we choose to focus on what is currently being read and discussed by activists as a much more substantive guide in identifying movement-relevant theory.

Our starting point is a question: if activists are hungry for insight and social movement theory isn't offering it, where are they looking? That is, if activists aren't reading the 
dominant contemporary theorists, what are they reading? This is the very question we asked a number of North American organizers in the global justice movement. Based on our conversations, our own experiences, and an informal survey, we assert that activists are reading widely about movements. Especially popular are histories of the US Civil Rights movement, like I've Got the Light of Freedom by Charles Payne (1996). Such histories offer a wealth of lessons, attractive to organizers, about building radical, largescale, genuinely diverse movements while successfully employing direct-action tactics and directly democratic organizing practices. Many activists additionally refer to autobiographies of organizers, such as Mab Segrest's Memoir of a Race Traitor (1994); as one respondent put it, 'they deal with the often ignored issues of burnout, emotional conflict, motivation, commitment' - all dimensions of movements that conventional academic theory has barely touched.

Activists also read work that is more explicitly theoretical. A book widely referenced is The Subversion of Politics, George Katsiaficas's (1997) history and analysis of European autonomous movements - including feminist, anti-nuclear, squatting, and anti-fascist currents - in the 1980s and 1990s. As one of the few works in English on these recent upsurges, Katsiaficas's book has particular resonance with those seeking to build nonhierarchical, decentralized alternative institutions and employ militant tactics. Also gaining much acclaim among activists recently is Robin Kelley's Freedom Dreams (2002), which, by highlighting movement visions, builds theory out of the long history of the African American freedom struggles in the USA.

An even more popular work is Jo Freeman's 'The tyranny of structurelessness' (1972), originally published in the Berkeley Journal of Sociology and since published in numerous pamphlet forms. This essay is perhaps the single most influential piece of US social movement theory in terms of use by actual movements. Freeman builds her analysis out of the women's liberation movement, arguing that seemingly 'structureless' groups in fact reproduce patterns of elitism, media 'stars', and political ineffectiveness. Instead she makes a case for directly democratic structures and sketches some key formative principles. Thirty years after her article was first published, it is still widely used in a variety of movement contexts, particularly trainings.

Activists are not only reading widely but also writing and conversing: meetings, email discussions, conferences, online essays, public talks, zines, study groups, magazine articles, trainings, cultural events, social forums, encuentros, and consultas are all wellused, vibrant means through which activists are self-consciously analyzing movements, exchanging ideas, and debating direction. Indeed, much of the most current and incisive material is only or mainly available through these media, not books.

This is all to suggest an important point: social movement scholars do not have a monopoly on theory about movements. Movement participants produce theory as well, although much of it may not be recognizable to conventional social movement studies. This kind of theory both ranges and traverses through multiple levels of abstraction, from everyday organizing to broad analysis. On the first level, as Elisabeth Clemens stresses, there is a 'rich and varied dialogue about organizing that suffuses social movements ...' (Clemens, 1996, p. 205). In other words, activists read, write, and talk extensively about organizing and other tactical questions, categorizing methods of mobilization with high degrees of specificity and depth.

One example is actions - demonstrations, mobilizations, and direct actions - which often constitute a locus for activist theorizing. In this regard, Katsiaficas's description of 
the German Autonomen is apt for other movements too: 'Preparations for actions, the actions themselves, and the inevitable (and often prolonged) soul-searching afterwards involve intensive theoretical reflection' (Katsiaficas, 1997, p. 202). ${ }^{8}$ This last point, concerning post-action reflection, is particularly crucial. For the global justice movement (and some sectors of the anti-war movement) the periods following large-scale protests and direct actions have seen an enormous outburst of lively debate and reflection. Such reflection involves expansive questions of goals, strategy, appropriate tactics, methods of organization, and means and ends (cf. Reclaim the Streets, 1999; Guilloud, 2000; Yuen et al., 2001; Albert, 2002; Klein, 2002; Starhawk, 2002; Notes from Nowhere, 2003). That these are grounded in actions should not serve to discount the quality of the theory. Indeed, as Perrow reminds us, 'One test of good theory is that it have practical implications' - a maxim that activists tend to take quite seriously.

While many scholars assume that activists are interested only in ideas related to immediate tactical issues, activists engage with theory at higher levels of abstraction as well, mixing crucial strategic questions with even broader critical concerns. Among sectors of the US and Canadian global justice movement, for instance, there is a rich ongoing discussion concerning power and exclusion within the movement itself. This exchange can be traced back to Elizabeth Martinez's influential essay 'Where was the color in Seattle?' (2000), which was written shortly after the Seattle protests against the World Trade Organization. Martinez observes that the thousands present in Seattle were 'overwhelmingly Anglo' and suggests, 'Understanding the reasons for the low level of color, and what can be learned from it, is absolutely crucial if we are to make Seattle's promise of a new, international movement against imperialist globalization come true.' By her account a central cause was the prevailing dynamic of marginalization in the predominantly white organizing leading up to the protests, a dynamic that was reflected in who was chosen to speak on behalf of protestors, how resources were allocated, who was making decisions, how issues were framed, and who was comfortable in organizing spaces (Martinez, 2000).

Writing a few months later, Colin Rajah (2000) points to a similar dynamic at the protests (known as A16) against the International Monetary Fund and World Bank in Washington, DC, in April 2000. In his words, 'the whiteness of the movement remained a thorny issue at A16' (Rajah, 2000). Meanwhile Chris Crass (2000), Pauline Hwang (2001), and Helen Luu (2004) began to extend and amplify this analysis. Crass focuses specifically on the role of white activists in the global justice movement and some of the problematic and counterproductive assumptions ingrained in prevailing organizing practices. He argues in particular that white activists shouldn't be asking 'how can we get people of color to join our groups and movement?' but rather 'How can we be anti-racist activists dedicated to bringing down white supremacy?' (Crass, 2000).

Hwang reflects on her experiences in Montreal organizing with both community-based organizations, composed mainly of working-class people of color, and in preparation for protests in Quebec City against the April 2001 Summit of the Americas. She contends that much of the summit-focused mobilization failed to build meaningful ties with community initiatives. Moreover, "it struck me how difficult it was to fully enjoy a mobilization seemingly designed for, and managed by, particularly types of activists' - namely, those who are predominantly white and middle class (Hwang, 2001).

Luu highlights this exclusion as well, cautioning against privileging a particular notion of 'radical activism' that is inaccessible to many. 'Who has the power', she asks, 'to decide 
what is "radical" in the first place and who gets left out because of that definition?' (Luu, 2004, p.423) Along with others, Luu also problematizes the boundaries between 'local' and 'global':

Oftentimes, issues that we perceive to take place in the South - IMF structural adjustment policies, agricultural cash crops, multinational sweatshops, etc. - are considered to be 'global' issues and effects of 'globalization' while issues we take notice of at home in the West - immigration, housing, welfare, etc. - are considered to be 'local' issues. (Luu, 2004, p. 424)

In reality they are 'integrally connected', she argues, and hence should be reflected in movement priorities (Luu, 2004, p. 423).

Many organizations, networks, and individual activists have since engaged in far-reaching critiques and self-critiques exploring the ways in which racism, sexism, classism, heterosexism, colonialism, and other systemic forms of oppression have operated even in seemingly 'liberatory' contexts (cf. Choudry, 2001; Dixon, 2001a; Guilloud, 2001; Hsiao, 2001; Katsiaficas, 2001; Sayegh, 2001; Singh, 2001; Wong, 2001; Yuen, 2001; Sivesind, 2002).

Others have criticized the parameters of the discussion. Amory Starr, for example, charges that "A particular "anti-racist" framework has become hegemonic in progressive and radical North American circles' (Starr, 2002, p. 269). She does not dispute that instances of exclusion are happening. Rather, citing Crass and others, she suggests that the 'hegemonic' logics for explaining and contending with dynamics of power and marginalization are self-enforcing and can exclude other logics and accounts (Starr, 2002, pp. 266-269). 'Do we deal with privilege', Starr asks, 'by berating individuals for having it or by mobilizing their affluence, flexibility, and tolerance in a strategy designed to win this struggle?' (Starr, 2002, p. 275). She consequently recommends carefully guarding 'a space for dissent and diversity' in order for those engaged in the movement to discuss the issues usefully (Starr, 2002, p. 276).

The richness of this dialogue ultimately lies not only in critique but also in offering new ways of strengthening and building vibrant radical movements. It delves into some of the most pressing questions of mobilization and internal movement dynamics. Along with a host of other examples, it constitutes an evolving, contentious body of theory, both referencing past movements and prescribing future directions. We might in fact consider interventions like these as 'meta-discourses' - reflexive conversations, written and verbal, about movement discourses - which perhaps constitute more familiar terrain for some scholars.

Anarchist and autonomist currents within the global justice movement provide numerous other examples. Take, for instance, the ongoing discussion about the role of 'the activist', originating in the large-scale anti-capitalist street actions in London on 18 June 1999 (known as J18), coinciding with the G8 summit in Cologne, Germany. Andrew X ${ }^{9}$ (1999) initiated this provocative conversation in his article 'Give up activism'. Reflecting on his experience at J18, he argues that the socially constructed role of 'the activist' is profoundly limiting and woefully inadequate for the task of doing away with capitalism. 'The activist', he notes, 'is a specialist or an expert in social change', which contradicts the very intent of anarchism - the abolition of privileged social roles. Further, 'Activism is based on this misconception that it is only activists who do social change - whereas of 
course class struggle is happening all the time.' He consequently contends that 'activists' must self-consciously scrutinize the activist role (X, 1999).

In one of the more notable responses, J. Kellstadt (2001) agrees with this premise but adds more complexity to Andrew X's critique: 'Social groups of whatever kind - be they cops, priests, and parents, or anarchists and activists - come into existence through complicated social processes.' And thus they cannot be individually 'willed away'. As a solution, Kellstadt proposes embracing 'simultaneously the necessity and the impossibility of "giving up activism". Kellstadt suggests 'living the tension' of this irreconcilable contradiction, struggling to revolutionize society while recognizing that it nonetheless shapes and constrains activist efforts and identities. This points, moreover, to a broader need for Kellstadt: 'the need for a theory to go with one's practice, a theory that can think the "subjective" and "objective" simultaneously, seeing them in all their mutuallyconditioning relatedness' (Kellstadt, 2001).

sasha $\mathrm{k}$ (k, 2001a), meanwhile, develops the substantial common ground between Andrew X and J. Kellstadt. Dialectically rejecting both overly subjective 'role-suicide' and overly objective social or historical determinism, he insists, 'there are always openings to different types of self-organization. We may not be able to kill the role, but we are not stuck in it either; and, if we are to rid ourselves of capitalism we need to struggle in a different way and not celebrate the role of the activist' (k, 2001a).

These contributions have spawned other interventions and much transnational debate (cf. Undercurrent, 2000; Dixon, 2001b; DuPont, 2001; k, 2001b; X, 2001). They have also sparked further discussions within activist groups and at least one national conference in the USA. Together they raise and address key questions of structure and agency, strategy and vision, and the limits and possibilities of radical action, among others. With fluidity generally absent from academic social movement theory, many of these contributions also move adeptly between levels of theoretical abstraction. In Andrew X's postscript to his original article, for instance, he addresses the confining aspects of single-issue campaign organizing as well as the nature of subjectivity, all with the ever-present question: 'what do we do as a radical minority that wants to create revolution in non-revolutionary times?' (X, 2001). Overall, this dialogue is of course oriented toward praxis but, as is characteristic of other movement-generated theory, it is nuanced, polyvalent, and always related to salient concerns.

Activists are thus fully capable of developing and elaborating sophisticated theory relevant to the movements in which they are engaged. And though it is mostly overlooked by social movement studies, this kind of theory has much to offer, and not only concerning the creative capacities of those involved in collective action. Indeed, social movement scholars should take guidance from it. The breadth and vibrancy of such theory suggests that relevance in the study of social movements can be found through critically engaging with the dialogues and questions that concern movements themselves.

\section{Methods of Movement-relevant Research}

Many, perhaps most, social movement scholars are drawn to this field not only by an interest in social movements but also sympathy and support for at least some movements. However, support for a movement does not in itself ensure that one's research findings will be relevant and useful for that movement. Indeed, at present this outcome is rather infrequent. Faced with this discrepancy, it is worth exploring whether particular methods 
of approaching social movement research are likely to shape the extent to which the results are useful to movements. Building on our examination of the theory production within movements, we would like to begin to outline a methodology for movement-relevant research with the understanding that this sketch is neither complete nor absolute. Our intention here is to foster a much-needed dialogue rather than present a finished blueprint.

While the previous section highlighted readings and theoretical discussions within the global justice movement, we do not wish to suggest that this methodology is specific to the global justice movement. There will certainly be some issues that are of greater interest to a particular movement at a particular time, though there are also many topics for social movement theory that are likely to be of interest to a wide variety of movements. Moreover, we believe that the principles for generating movement-relevant theory are applicable to social movements generally.

Foremost in generating useful findings is to start by locating the issues and questions of most importance to movement participants. This requires a direct examination of the discussions taking place within a given movement. As we have seen, social movement analysis and theory is situated not only within the academy. Movement participants are actively involved in these processes, though often in contexts that are separate from academic discourses. These activist discussions offer crucial insights into the issues of greatest concern to the movements, and they thus provide an important starting point for developing movement-relevant research topics. From this foundation researchers can identify the particular questions and issues that may be most pertinent for specific movements or segments of those movements.

In examining these activist discussions, there are three key questions to explore: what issues concern movement participants? What ideas and theories are activists producing? What academic scholarship is being read and discussed by movement participants? Within these queries, social movement scholarship would, of course, focus on those concerns related directly to the dynamics of the movements themselves, such as questions about structure, effectiveness, strategy, tactics, identity, relations to the state, relations to the media, the dynamics of their opponents, etc. An exploration of these questions should help to identify the areas for social movement research that are of greatest concern to the movements themselves.

Our discussion of the global justice movement provides a useful example. Based on our experience, research, and analysis, we might suggest that some key questions of concern for that movement, as well as sites of considerable theory production, center on tactics, strategy, and movement building, which are all, of course, interrelated: how to effectively use direct action tactics and directly democratic organizing practices? How to contend with thorny issues of power and exclusion as they operate within movements? How to build radical, large-scale, genuinely diverse movements and alternative institutions? And, as Andrew $\mathrm{X}$ asks, 'what do we do as a radical minority that wants to create revolution in non-revolutionary times?' (X, 2001). These are all questions with which activists are grappling. In one way or another, much of the work that they are reading and writing seeks to address them. With careful attention to the discussions in which they are embedded, all are potentially rich starting points for movement-relevant work.

While it is important to look to movements to identify useful research questions, it is also possible for scholars to produce relevant research on issues that have not been highlighted by movement participants. Yet in these cases it is important to remain in direct dialogue with the movements, or what may seem like helpful suggestions from scholars 
may instead be perceived as unhelpful or even counterproductive by activists. For instance, Earth First! organizer Judi Bari, who had worked to build alliances between environmentalists and timber workers, expressed frustration with academic analyses that criticized Earth First! for not engaging in greater outreach to workers. Such analyses overlooked the crucial role of repression and violence against alliance organizers in limiting such work, and instead seemed to place blame unfairly on the activists (Bevington, 1998).

Direct engagement with movements is also important during the research process. Scholars who rely too heavily on secondary sources are not contributing new information and more often simply perpetuate limited or outdated analyses. For example, all too often academic accounts of Earth First! in the USA repeat a handful of sensationalistic quotes from rather obscure and dated sources (cf. Dumont, 1991; Van Wyck, 1997). These recycled passages lead to a narrow and largely inaccurate view of the movement that does not reflect the perspectives of contemporary Earth First! activists (Scarce, 1990; Ingalsbee, 1995; Bevington, 1998). There is simply no substitute for direct engagement with movements. ${ }^{10}$

Engagement with the movements should not end with the completion of the research. If one's goal is to create movement-relevant scholarship, it is crucial to examine how one's work is received by activists. This also offers an important way to 'test' the research both for its utility and its accuracy and thereby improve the quality of one's scholarship. To return to the previous example, John Bellamy Foster's first published analysis of Earth First! (Foster, 1993) was sharply critiqued by activist Judi Bari. But this led to a productive dialogue between Foster and Bari. Out of this dialogue, Foster later revised his article to address many of Bari's concerns. The result was a more nuanced assessment of that movement that was also more likely to engage movement participants (Foster, 1998).

It should be clarified, however, that a critical response from some movement participants to one's research does not necessarily negate the movement-relevant character of such work. As noted above, movement-relevant scholarship is not an uncritical affirmation of movements. Indeed, some of the most helpful research challenges the assumptions upon which movements are developing strategies, such as Piven and Cloward's critical examination of the role of social movement organizations, cited above (Piven \& Cloward, 1977). Such findings challenge the status quo within the movement. As such, while it is important and useful, this research may also be disturbing for some movement participants invested in that status quo and will likely receive criticism, at least in the short term. The best way to ascertain whether criticism reflects legitimate problems with the research or simply the vested interests of the critic is through committed and continuous dialogue between the researcher and the activists. If both parties are genuinely concerned with the success of the movement, research that is accurate and useful should weather such controversy.

Ultimately, a key test of movement-relevant research is whether it is read by activists and incorporated into movement strategizing. If one's goal is to produce useful information for movements, but the movements are not using this research, it is incumbent on the researcher to ask why. Is the research exploring questions that really matter to movements? Are important issues being overlooked in the research process? Is feedback from the activists being incorporated sufficiently into the research conclusions? And are these findings being made available in a form, style, and location that is accessible to activists outside of the academy? 
Direct engagement with movements is therefore needed throughout the research process, with particular attention to the formulation and impact of that research. This deepened connection consists of more than just working directly with movement participants. It is a process of relationship building that may take significant work on the part of the researcher. In part, this comes about through treating movement participants as capable and active participants in the generation of theory. For example, John Brown Childs (2003) sets aside more than half of his book on 'transcommunality' to allow activists as well as other scholars to respond directly to this theory, even when those responses are notably critical. In addition, scholars can draw on institutional resources to offer time and opportunity for some activists to pursue more extended reflection. With this sort of reciprocity, trust and dynamic engagement between scholars and activists can grow.

This deepened relationship brings with it important challenges for the researcher. With the bonds of trust come increased responsibilities around issues of confidentiality, especially for movements involved in direct action. For example, sociologist Rik Scarce was jailed for 159 days for not revealing to a grand jury the names of the animal rights activists he had interviewed (Scarce, 2001). More direct engagement may also lead to emotional attachments or create pressures on scholars seeking to maintain good relationships with movement participants. We need to take such issues seriously to ensure that they don't undermine sound scholarship. But at the same time, it is important not to overstate them. And, as discussed above, direct connection to a movement actually fosters incentives for more accurate scholarship. This is true whether studying a favored movement or its opposition, such as with the example of Sara Diamond's studies of the Christian Right.

Direct engagement is not simply chumminess with a favored movement. It is about putting the thoughts and concerns of the movement participants at the center of the research agenda and showing a commitment to producing accurate and potentially useful information about the issues that are important to these activists. This is a principal foundation for building a dynamic and reciprocal engagement with movement participants. One result of this engagement is better research as scholars develop deeper and more nuanced understandings of movements.

It is also important to consider how that research can then contribute to the production of useful theory. As noted above, activists are capable of generating their own theory through readings of academic case studies and histories of movements. But academics can aid this process by combining analyses of a broad variety of movements to draw out larger lessons and presenting them in a form that is more readily applicable by activists. In this regard we would like to highlight the value of multi-movement comparative analysis in the production of movement-relevant theory. As noted above, Katsiaficas's examination of the different European autonomous movements has been widely read by activists in the global justice movement (Katsiaficas, 1997). Likewise, Barbara Epstein (1991) has compared the experiences of various American non-violent direct-action campaigns of the 1970s and 1980s in order to inform the theory around those movements. In other cases, comparisons of more dissimilar movements can also lead to important theoretical contributions, as exemplified by Piven and Cloward's Poor People's Movements (1977).

In some cases, the scope of these comparative projects is so vast that it would be difficult to imagine full-time activists finding the time and resources to pursue such studies. Nowhere is this more evident than William Gamson's classic The Strategy of Social Protest ([1975] 1990). Gamson's research is centered on a fundamentally useful question: what social movement structures and strategies influence the movements' effectiveness? 
To answer this question, he studies the successes and failures of a sample of fifty-three 'challenging groups' in America between 1800 and 1945. This vast comparative study sheds light on strategic choices which still face contemporary movements: radical demands versus 'thinking small', single issue versus multi-issue, large versus small groups, violence versus non-violence, etc. Again, it is difficult to imagine a project of this scope being conducted outside of the academy. In this regard, Gamson's work stands as an important example of the particular potential for scholars to contribute to movementrelevant theory.

\section{Recovering Relevance}

One might note that Gamson's Strategy of Social Protest was first written more than a quarter of a century ago. While we contend that the present conditions offer a particularly strong opportunity for the success of movement-relevant theory (as we shall discuss in the conclusion), it is important to recognize that there is a long but neglected legacy of social movement scholarship that has been useful to movements. However, with previous developments in social movement theory, the successful rise of a new school of thought frequently depended on a devaluation (and often mischaracterization) of the previous schools in order to lend credence to prioritizing the new favored variable in the social movement lifecourse. 'The result', as Jasper notes, 'is often an oscillation between unrealistic extremes, with each generation forgetting the insights of those before it' (Jasper, 1997, p. 19).

Movement-relevant theory sidesteps this unfortunate tendency. Because it does not seek to focus on another variable in the movement lifecourse, this approach does not require a sweeping rejection of prior social movement analysis. Instead, it offers the prospect of rediscovery and recovery of the movement-relevant elements of earlier scholarship that can be useful for activists and scholars today. Thus, a movement-relevant approach can develop through the consideration of the present needs of social movements, the growth of movement-minded methodologies to guide future research, and the recovery of what is most useful from the past.

A full process of recovering the movement-relevant elements of past social movement research is of course well beyond the scope of this paper, but that should not prevent us from sketching an outline. A logical starting point is among the origin stories for social movement theory. At present, the dominant accounts in American sociology (McAdam et al., 1988; McAdam, 1999) begin with Gustav LeBon's The Crowd ([1895] 1960) and move fairly rapidly to William Kornhauser's The Politics of Mass Society (1959). This early social movement theory is characterized by a distinct antipathy toward social movements in which they are seen as dangerous, irrational, and even pathological. One would not expect such work to be of much use to movement participants.

Thus if one wants to find early theory that informs social movement activity, it is necessary to look beyond those theorists discussed above. In short, one must call into question who gets included in the canon of classical social movement theory. For example, why should accounts of social movement theory begin with Le Bon when Marx and Engels were directly addressing social movements a half century before him? Indeed, Flacks suggests that the Communist Manifesto is not only one of the earliest examples of social movement theory but also that it 'remains the only full-fledged theory about the conditions and powers of movements that we have' (Flacks, 2004, p. 138). Similarly, Tarrow criticizes the prevailing omissions of early Marxists from the lineage of social movement 
theory, highlighting the contributions of Lenin and Gramsci in particular (Tarrow, 1998). Certainly one cannot deny the vast influence of these theorists on social movements.

Moving forward, the 1960s and 1970s offer a particularly promising era for the recovery of movement-relevant work. As Flacks reminisces:

Many of those who studied social movements in the 1960s and 1970s were themselves politically active. My impression then was that most of them believed the study of social movements ought to provide movement activists with intellectual resources they might not readily obtain otherwise ... Work in that vein indeed proved to be directly useful to activists; some of the research and theorizing of academic sociologists helped shape movement training programs and handbooks. It was possible to imagine, if you were engaged in social movement studies, that your teaching, consulting, and direct participation as well as your research efforts themselves, might have some relevance to the practices and understandings of political activists. (Flacks, 2004, p. 136)

It is not surprising, then, that many of the works we have mentioned in this paper come from that era. Some of that work, such as Freeman's 'Tyranny of structurelessness', remains widely read by activists (cf. Kahl, 2001) even if it has slipped to a more marginal role in the genealogies of social movement theory. A less marginalized example is Piven and Cloward's Poor People's Movements (1977). Piven and Cloward not only explored issues of clear relevance to activists, particularly the role of social movement organizations in social change, but also sought to directly apply their theory within the welfare rights movement. However, their critique of the importance of social movement organizations was at odds both with the resource mobilization theory of the time as well as the political process theory that would emerge a few years later. As a result, while their book remains widely read in the academy, it has not fit comfortably into the academic canon of social movement theory.

More recently, 'During the 1980s and 1990s, the gap between activists and academics seemed to widen' (Darnovsky et al., 1995b, p. xvi). This is not to say that no useful American social movement scholarship emerged during this era. For example, Charlotte Ryan, a protégé of Gamson, produced Prime Time Activism (1991), a book on the media that sought to speak both to social movement theorists and to activists. And some scholars who explicitly identified with PPT created work that was helpful to movements - for example, Sara Diamond's Not by Politics Alone ${ }^{11}$ (1998). But more often, the most movement-relevant work came from scholars working outside of the dominant approach to social movement theory, such as Barbara Epstein's Political Protest and Cultural Revolution (1991), George Katsiaficas's The Subversion of Politics (1997), and many of the contributions to Cultural Politics and Social Movements (Darnovsky et al., 1995a).

By the late 1990s and early 2000s there was some more concerted attention given to the relation between activism and social movement research. For example, Verta Talor (1998) and Kathleen Blee (1998) sought to apply feminist methodologies to social movement studies to challenge the ideal of the detached researcher and to build the connection between researcher and activist. Likewise, Sharon Kurtz drew on her own activism to develop social movement theory in Workplace Justice (2002). There has also been growing attention to the connection between research and activism in social science methodologies centered on various forms of community-based and participatory action 
research (cf. Stringer, 1996; McTaggart, 1997; Murphy et al., 1997). But by and large these developments have not been reflected in the dominant social movement theory.

A recurring theme in this history is that often the most movement-relevant scholarship takes place at the margins of the dominant theoretical paradigms. Yet the lack of a common identity or framework to unite these scholars as a full-fledged alternative has contributed to the ongoing marginalization of such work within the field. Part of the promise of a movement-relevant approach is that it offers such an alternative framework to connect this scholarship, past, present, and future. ${ }^{12}$

\section{Conclusion: Why Now?}

We are living in a time of worldwide insurgency - from mass land occupations of Brazil's Movimento dos Sem Terra to the 'carnivals against capitalism' of England's Reclaim the Streets, from Indian farmers burning Monsanto's biotech crops to the indigenous Nigerian struggles against Shell Petroleum, from mass movements in South Korea challenging US military bases to the Zapatistas' struggle for autonomy in the face of Mexican military occupation. Meanwhile, traversing the globe - in Berlin, Manila, Vancouver, Geneva, Washington, DC, Prague, Quebec City, Quito, Cancun, Miami, and many other instances hundreds of thousands have protested international summits of the World Trade Organization, the International Monetary Fund, the Asian Development Bank, the World Bank, the Organization of American States, and others. Most recently, millions worldwide mobilized against a war on Iraq. In the USA this upsurge in social movement activity is most clearly marked by the successful protest in Seattle during the WTO Ministerial, but is also evident in subsequent global justice mobilizations and massive anti-war demonstrations, as well as the growing movement against the prison industrial complex.

The confrontations are growing and the stakes are high. These circumstances, taken together, call for theory useful to and engaged with movements. The dominant American social movement theory, however, has little to offer here. Indeed, the detached approach to social movement scholarship has had its run of the course and its shortcomings are now quite evident. Increased attention to more or different variables in the social movement lifecourse will not fix this problem. Moreover, it is important to note that this approach emerged during a period of relative quiescence for American social movements, particularly in contrast to the upheavals of the 1960s and 1970s as well as the present. Under such staid conditions, one can see how social movement scholars would be influenced more strongly by professional considerations (Flacks, 2004). ${ }^{13}$

There is an alternative. The current circumstances potentially provide a context for scholars to grapple with important questions and develop useful analyses. Resurgent movements create renewed incentives for scholars to undertake movement-relevant research. Vibrant movements also provide an important countervailing source of accountability for scholars besides professional demands. With such resurgence, in turn, comes a new generation of activist-intellectuals, both in and outside the academy, with stronger links to movements. ${ }^{14}$ Growing from these sources, we see a promising, emerging movement-relevant approach, one based on direct, dynamic engagement with the concerns and questions of movements themselves. Movement-relevant theory offers a framework for further cultivating this kind of engagement and for injecting renewed vigor into the field of social movement studies. 


\section{Notes}

1. While other terms are also used to describe this tradition, such as political opportunity theory, we will use 'political process theory' both because that was the term used as this approach was being developed and because it is the term used in some of the most notable critiques of this approach.

2. Although imperfect, we prefer this label to 'anti-globalization movement', which, as David Graeber notes, 'is a coinage of the US media and activists have never felt comfortable with it. ... Insofar as this is a movement against anything, it's against neoliberalism ...' (Graeber, 2003, p. 326). He champions 'globalization movement' as an alternative, but 'global justice movement' is the self-description we have found most widely accepted among activists from different sectors of the movement.

3. With this focus on American scholarship, we will not be giving direct attention to the body of European social movement analysis gathered together under the rubric of 'new social movement theory'. While these works received notable attention among American scholars in the late 1980s and early 1990s, producing exciting dialogues between new social movement theory and American resource mobilization theory (Morris \& Mueller, 1992; Darnovsky et al., 1995a), in the subsequent decade they have largely been supplanted in the dominant American social movement literature by a focus on political process theory. Today, the influence of new social movement theory is more apparent in cultural studies circles than in the mainstream social movement studies in the USA, though its legacy is certainly evident in the 'culturalist' strand of social movement analysis promoted by Goodwin and Jasper (1999a; Jasper, 1997). However, the elements of new social movement theory which sought to develop strengthened connections between movements and social movement theory, such as Touraine's 'sociological intervention' method (Touraine, 1981), have attracted little interest from US scholars. For an assessment of the impact of new social movement theory on US movements, see Epstein (1991).

4. Consideration of the relevance of social movement theory to movements has received surprisingly scant attention in recent scholarship. David Meyer mentions it in his introduction to Social Movements: Identity, Culture, and the State (2002, pp. 6-7). Otherwise, Flacks' article - along with some of Flacks' earlier work (Darnovsky et al., 1995b) - serves as an almost singular beacon in this respect. [An important addition to this scant literature-published just as our article goes to press-is Rhyming Hope and History: Activists, Academics, and Social Movement Scholarship (Croteau et al. 2005), a tribute to William Gamson in which the contributors explore the relationship between social movement scholarship and activism.]

5. Of course, the environmental, global justice, and anti-war movements do not represent the full breadth of social movement forms. We do not wish to engage in what Jasper calls empirical overextension (Jasper, 1997, p. 41). And certainly there is need for a more thorough assessment of the influence that contemporary social movement theory has on other social movements. We choose to focus on these movements because we have the most familiarity with them, both through our research and experience. Moreover, we have not encountered any indication in our conversations with activists or in the academic literature that this scholarship is notably influencing other types of social movements.

6. There is a long tradition of academic scholarship outside of social movement studies that has direct bearing on the work of social movements. A recent example would be the critical criminology (cf. Currie, 1985) and drug policy scholarship (cf. Reinarman \& Levine, 1997) that informs the growing movement against the prison industrial complex. Some research has even helped facilitate the emergence and growth of social movements (e.g. environmental sociology in relation to the environmental justice movement; cf. Bullard, 1990). [On a broader scale, since the initial writing of this article, the discussions of the overall relevance of sociological scholarship to society have benefited greatly from Michael Burawoy's explorations of 'public sociology' (Burawoy, 2005).]

7. In addition to research from institutions of social control, activists are also reading the opposition research being done by the business community to counter anti-corporate campaigns, such as Denise Deegan's Managing Activism: A Guide to Dealing with Activists and Pressure Groups (2001). For examples of how activists are using such work to inform their own strategies, see John Stauber's review of Deegan's book (Stauber, 2003) and Tom Hayden's analysis of a similar study (Hayden, 2001).

8. Similarly, in the context of the US non-violent direct action movement, Noel Sturgeon (1995) highlights activist theorizing as it is embedded in practice, which she calls 'direct theory'.

9. Pseudonyms like this one are particularly prevalent among these currents of the global justice movement. Katsiaficas discusses this in the context of European autonomous movements: 'The nearly universal practice of signing articles in movement publications with pseudonyms emphasizes ideas, not personalities. Readers 
are thereby compelled to consider arguments on their own merit rather than for the prominence or ideological allegiance of their authors' (Katsiaficas, 1997, p. 201).

10. Of course, this presents obvious challenges for researching historical movements. But even in this case, direct engagement with similar contemporary movements is likely to provide the researcher with a better understanding of the internal dynamics and concerns of the historic movement.

11. However, Diamond's book is atypical of PPT in the high level of attention it gives to issues of culture.

12. However, we do not wish to suggest that the articulation of this framework represents the sole basis for our contention that a movement-relevant approach represents a promising direction for social movement theory. What is going on here is more than the introduction of a new term. Instead, as we discuss in the conclusion, many features of the current political and academic landscape are contributing to such a direction, irrespective of our attempts to provide a framework for those tendencies in this paper.

13. This is certainly not to minimize ongoing institutional constraints specific to the academy that effect a disconnect between social movement scholarship and the concerns of activists. Examples include eligibility requirements for tenure, the need to direct research toward academic peers, and increasing committee and teaching workloads. Unfortunately, exploring such constraints is well beyond the scope of this essay. See Barker and Cox (2001) for further discussion.

14. The editors of the collection The Battle of Seattle: The New Challenge to Capitalist Globalization (Yuen et al., 2001) embody these two facets of the new generation working in conjunction with a member of an earlier generation of movement-relevant scholars. Eddie Yuen is a PhD candidate in Sociology and Daniel Burton Rose is a movement writer and researcher. They collaborated with George Katsiaficas, a longtime social movement scholar whose work around European autonomous movements has been particularly influential for global justice activists. An updated version of this book, with substantial new material, has recently been released under the title Confronting Capitalism: Dispatches from a Global Movement (Yuen et al., 2004). Likewise, another recent volume, We Are Everywhere: The Irresistible Rise of Global Anticapitalism (Notes from Nowhere, 2003), brings together an impressive set of activists, including both academics and independent intellectuals, from across the globe to reflect and report on anti-capitalist currents in the global justice movement.

\section{References}

Albert, M. (2002) The Trajectory of Change: Activist Strategies for Social Transformation (Cambridge, MA: South End Press).

Arquilla, J. \& Ronfeldt, D. (1996) The Advent of Netwar (Santa Monica: RAND).

Arquilla, J. \& Ronfeldt, D. (Eds) (2001) Networks and Netwars: The Future of Terror, Crime, and Militancy (Santa Monica: RAND).

Barker, C. \& Cox, L. (2001) 'What have the Romans ever done for us?'. Academic and activist forms of movement theorizing. Available at http://www.iol.ie/ mazzoldi/toolsfor change/afpp/afpp8.html (accessed 10 March 2004).

Bevington, D. (1998) Earth First! in Northern California: an interview with Judi Bari. in: D. Faber (Ed.) The Struggle for Ecological Democracy: Environmental Justice Movements in the United States, pp. 248-271 (New York: Guilford Press).

Blee, K. (1998) White-knuckle research: emotional dynamics in fieldwork with racist activists. Qualitative Sociology, 21(4), pp. 381-399.

Bullard, R. (1990) Dumping in Dixie: Race, Class, and Environmental Quality (Boulder, CO: Westview Press).

Burawoy, M. (2005) For public sociology. American Sociological Review, 70(1), pp. 4-28.

Canadian Security Intelligence Service (2000) Anti-globalization - a spreading phenomenon. Available at http://www.csis-scrs.gc.ca/eng/miscdocs/200008_e.html (accessed 10 March 2004).

Childs, J. (2003) Transcommunality: From the Politics of Conversion to the Ethics of Respect (Philadelphia: Temple University Press).

Choudry, A. (2001) Bringing it all back home: anti-globalisation activism cannot ignore colonial realities. Available at http://www.zmag.org/sustainers/content/2001-08/03choudry.htm (accessed 10 March 2004).

Clemens, E. (1996) Organization form as frame: collective identity and political strategy in the American labor movement, 1880-1920. in: D. McAdam, J. McCarthy \& M. Zald (Eds) Comparative Perspectives on Social Movements: Political Opportunities, Mobilizing Structures, and Cultural Framings, pp. 205-226 (Cambridge: Cambridge University Press). 
Crass, C. (2000) Beyond the whiteness - global capitalism and white supremacy: thoughts on movement building and anti-racist organizing. Available at http://colours.mahost.org/articles/crass4.html (accessed 10 March 2004).

Croteau, D., Hoyness, W. \& Ryan, C. (Eds) (2005) Rhyming Hope and History: Activists, Academics, and Social Movement Scholarship (Minneapolis: University of Minnesota Press).

Currie, E. (1985) Confronting Crime: An American Challenge (New York: Pantheon Books).

Darnovsky, M., Epstein, B. \& Flacks, R. (Eds) (1995a) Cultural Politics and Social Movements (Philadelphia: Temple University Press).

Darnovsky, M., Epstein, B. \& Flacks, R. (1995b) Introduction. in: M. Darnovsky, B. Epstein \& R. Flacks (Eds) Cultural Politics and Social Movements, pp. vii-xxiii (Philadelphia: Temple University Press).

Deegan, D. (2001) Managing Activism: A Guide to Dealing with Activists and Pressure Groups (London: Kogan Page).

Diamond, S. (1998) Not by Politics Alone: The Enduring Influence of the Christian Right (New York: Guilford Press).

Dixon, C. (2001a) Finding hope after Seattle: rethinking radical activism and building a movement. ONWARD 1, Spring, p. 14+.

Dixon, C. (2001b) Reflections on privilege, reformism, and activism: a reply to sasha k. Available at http://users. resist.ca/ chrisd/reflecting/reply.htm (accessed 10 March 2004).

Dumont, C. (1991) Loggers and radical environmentalists: cultural struggles in timber country. PhD Dissertation., Department of Sociology, University of Oregon.

DuPont, M. (2001) Your face is so mysteriously kind. Available at http://www.geocities.com/kk_abacus/ioaa/ face.html (accessed 10 March 2004).

Epstein, B. (1991) Political Protest and Cultural Revolution: Nonviolent Direct Action in the 1970s and 1980s (Berkeley: University of California Press).

Flacks, R. (2004) Knowledge for what? Thoughts on the state of social movement studies. in: J. Goodwin \& J. Jasper (Eds) Rethinking Social Movements: Structure, Culture, and Emotion, pp. 135-153 (Lanham, MD: Rowman \& Littlefield).

Foster, J. (1993) The Limits of Environmentalism without Class: Lessons from the Ancient Forest Struggle in the Pacific Northwest (New York: Monthly Review Press/Capitalism, Nature, Socialism pamphlet).

Foster, J. (1998) The limits of environmentalism without class: lessons from the ancient forest struggle in the Pacific northwest. in: D. Faber (Ed.) The Struggle for Ecological Democracy: Environmental Justice Movements in the United States, pp. 188-217 (New York: Guilford Press).

Freeman, J. (1972) The tyranny of structurelessness. Berkeley Journal of Sociology, 17, pp. 151-164.

Gamson, W. ([1975] 1990) The Strategy of Social Protest, 2nd edition, (Belmont: Wadsworth).

Goodwin, J. \& Jasper, J. (1999a) Caught in a winding, snarling vine: the structural bias of political process theory. Sociological Forum, 14(1) pp. 27-54.

Goodwin, J. \& Jasper, J., ['Jaswin'] (1999b) Trouble in paradigms. Sociological Forum, 14(1), pp. $107-125$.

Graeber, D. (2003) The globalization movement and the new New Left. in: S. Aronowitz \& H. Gautney (Eds) Implicating Empire: Globalization and Resistance in the 21st Century World Order, pp. 325-338 (New York: Basic Books).

Green, J. (2000) Taking History to Heart: The Power of the Past in Building Social Movements (Amherst: University of Massachusetts Press).

Guilloud, S. (Ed.) (2000) Voices from the WTO: An Anthology of Writings from the People Who Shut Down the World Trade Organization (Olympia, WA: The Evergreen State College).

Guilloud, S. (2001) Spark, fire, and burning coals: an organizer's history of Seattle. in: E. Yuen, G. Katsiaficas \& D. Rose (Eds) The Battle of Seattle: The New Challenge to Capitalist Globalization, pp. 225-231 (New York: Soft Skull Press).

Hayden, T. (2001) Co-opting the radical instinct: a warning. in: N. Welton \& L. Wolf (Eds) Global Uprising: Confronting the Tyrannies of the 21st Century, pp. 73-75 (Gabriola Island, BC: New Society).

Hsiao, A. (2001) Color blind: activists of color bring the economic war home, but is the movement missing the message? in: E. Yuen, G. Katsiaficas \& D. Rose (Eds) The Battle of Seattle: The New Challenge to Capitalist Globalization, pp. 343-346 (New York: Soft Skull Press).

Hwang, P. (2001) Anti-racist organizing: reflecting on lessons from Quebec City. Available at http://colours. mahost.org/articles/hwang3.html (accessed 10 March 2004).

Ingalsbee, T. (1995) Earth First!: consciousness in action in the unfolding of a new-social-movement. PhD Dissertation, Department of Sociology, University of Oregon.

Jasper, J. (1997) The Art of Moral Protest: Cultural, Biography, and Creativity in Social Movements (Chicago: University of Chicago Press). 
k, s. (2001a) 'Activism' and 'anarcho-purism'. Available at http://www.infoshop.org/rants/kk_purism.html (accessed 10 March 2004).

k, s. (2001b) Dirty mirrors and deformed reflections. Available at http://www.geocities.com/kk abacus/ioaa/sasha2.html (accessed 10 November 2002).

Kahl, L. (2001) The tyranny of structurelessness and Earth First!. Earth First! Journal, pp. May-June, 34+.

Katsiaficas, G. (1997) The Subversion of Politics: European Autonomous Social Movements and the Decolonization of Everyday Life (Atlantic Highlands, NJ: Humanities Press).

Katsiaficas, G. (2001) Seattle was not the beginning. in: E. Yuen, G. Katsiaficas \& D. Rose (Eds) The Battle of Seattle: The New Challenge to Capitalist Globalization, pp. 29-35 (New York: Soft Skull Press).

Kelley, R. (2002) Freedom Dreams: The Black Radical Imagination (Boston: Beacon Press).

Kellstadt, J. (2001) The necessity and impossibility of 'anti-activism'. Available at http://www.infoshop.org/ rants/antiactivism.html (accessed 10 March 2004).

Klein, N. (2002), in: D. Levy (Ed.) Fences and Windows: Dispatches from the Front Lines of the Globalization Debate (New York: Picador).

Kornhauser, W. (1959) The Politics of Mass Society (Glencoe: Free Press).

Kurtz, S. (2002) Workplace Justice: Organizing Multi-identity Movements (Minneapolis: University of Minnesota Press)

Le Bon, G. ([1895]1960) The Crowd: A Study of the Popular Mind (New York: Viking).

Luu, H. (2004) Discovering a different space of resistance: personal reflections on anti-racist organizing. in: D. Solnit (Ed.) Globalize Liberation: How to Uproot the System and Build a Better World pp. 411-426 (San Francisco: City Lights Press).

Martinez, E. (2000) Where was the color in Seattle? Looking for reasons why the Great Battle was so white. ColorLines, 3(1), Available at: http://www.arc.org/C_Lines/CLArchive/ story3_1_02.html (accessed 10 March 2004).

McAdam, D., McCarthy, J. \& Zald, M. (1988) Social movements, in N. Smelser (Ed.). Handbook of Sociology, pp. 695-737 (Newbury Park: Sage).

McAdam, D. (1999) Political Process and the Development of Black Insurgency, 1930-1970, 2nd edition, (Chicago: University of Chicago Press).

McAdam, D., Tarrow, S. \& Tilly, C. (2001) Dynamics of Contention (Cambridge: Cambridge University Press).

McTaggart, R. (Ed.) (1997) Participatory Action Research: International Contexts and Consequences (Albany: State University of New York Press).

Meyer, D. (1999) Tending the vineyard: cultivating political process research. Sociological Forum, 14(1), pp. 79-92.

Meyer, D. (2002) Opportunities and identities: bridge-building in the study of social movements. in: D. Meyer, N. Whittier \& B. Robnett (Eds) Social Movements: Identity, Culture, and the State, pp. 3-21 (New York: Oxford University Press).

Morris, A. \& Mueller, C. (Eds) (1992) Frontiers in Social Movement Theory (New Haven: Yale University Press).

Murphy, D., Scammell, M. \& Schlove, R. (Eds) (1997) Doing Community-based Research: A Reader (Amherst: Loka Institute and Community Partnership Center, University of Kentucky).

Notes from Nowhere (Ed.) (2003) We Are Everywhere: The Irresistible Rise of Global Anticapitalism (London: Verso).

Payne, C. (1996) I've Got the Light of Freedom: The Organizing Tradition and the Mississippi Freedom Struggle (Berkeley: University of California Press).

Perrow, C. (1970) Organizational Analysis: A Sociological View (Belmont, CA: Brooks/Cole).

Piven, F. \& Cloward, R. (1977) Poor People's Movements: Why They Succeed, How They Fail (New York: Vintage Books).

Rajah, C. (2000) Globalism and race at A16 in D.C.. ColorLines, 3(3), Available at http://www.arc.org/C_Lines/ CLArchive/story3_3_01.html (accessed 10 March 2004).

Reclaim the Streets (Ed.) (1999) Reflections on J18. Available at http://www.infoshop.org/octo/j18_reflections. html (accessed 10 March 2004).

Reinarman, C. \& Levine, H. (Eds) (1997) Crack in America: Demon Drugs and Social Justice (Berkeley: University of California Press).

Ryan, C. (1991) Prime Time Activism: Media Strategies for Grassroots Organizing (Boston: South End Press).

Sayegh, G. (2001) Redefining success: white contradictions in the anti-globalization movement. Available at http://colours.mahost.org/articles/sayegh.html (accessed 10 March 2004).

Scarce, R. (1990) Eco-warriors: Understanding the Radical Environmental Movement (Chicago: Noble Press). 
Scarce, R. (2001) Scholarly ethics and courtroom antics: where researchers stand in the eyes of the law. in: J. Miller \& R. Tewksbury (Eds) Extreme Methods: Innovative Approaches to Social Science Research, pp. 258-272 (Boston: Allyn \& Bacon).

Segrest, M. (1994) Memoir of a Race Traitor (Boston: South End Press).

Singh, J. (2001) Resisting global capitalism in India. in: E. Yuen, G. Katsiaficas \& D. Rose (Eds) The Battle of Seattle: The New Challenge to Capitalist Globalization, pp. 48-50 (New York: Soft Skull Press).

Sivesind, S. (2002) Combating white privilege in the anti-globalization movement. Clamor, March/April, pp. $65-70$.

Starhawk (2002) Webs of Power: Notes from the Global Uprising (Gabriola, BC: New Society).

Starr, A. (2002) Is the North American anti-globalization movement racist? Critical reflections. in: L. Panitch \& C. Leys (Eds) Socialist Register 2003: Fighting Identities: Race, Religion and Ethno-nationalism, pp. 265-280 (New York: Monthly Review Press).

Stauber, J. (2003) Managing activism: PR advice for 'neutralizing' democracy [Book Review]. PR Watch, 19 February.

Stringer, E. (Ed.) (1996) Action Research: A Handbook for Practitioners (Thousand Oaks, CA: Sage).

Sturgeon, N. (1995) Theorizing movements: direct action and direct theory. in: M. Darnovsky, B. Epstein \& R. Flacks (Eds) Cultural Politics and Social Movements, pp. 35-51 (Philadelphia: Temple University Press).

Tarrow, S. (1998) Power in Movement: Social Movements and Contentious Politics, 2nd edition, (Cambridge: Cambridge University Press).

Taylor, V. (1998) Feminist methodology in social movements research. Qualitative Sociology, 21(4), pp. $357-379$.

Tilly, C. (1999) Wise quacks. Sociological Forum, 14(1), pp. 55-61.

Touraine, A. (1981) The Voice and the Eye (New York: Cambridge University Press).

Undercurrent (2000) Practice and ideology in the direct action movement. Available at http://www.geocities. com/kk_abacus/ioaa/pracideo.html (accessed 10 March 2004).

Van Wyck, P. (1997) Primitives in the Wilderness: Deep Ecology and the Missing Human Subject (Albany: State University of New York Press).

Wong, K. (2001) The showdown before Seattle: race, class, and the framing of the movement. in: E. Yuen, G. Katsiaficas \& D. Rose (Eds) The Battle of Seattle: The New Challenge to Capitalist Globalization, pp. 215-224 (New York: Soft Skull Press).

X, A. (1999) Give up activism. in: Reclaim the Streets (Ed.) (Ed.) Reflections on June 18, Available at http:// www.infoshop.org/octo/j18_rts1.html (accessed 10 March 2004).

X, A. (2001) Give up activism: postscript. Available at http://www.eco-action.org/dod/no9/ activism_postscript.htm (accessed 10 March 2004).

Yuen, E. (2001) Introduction. in: E. Yuen, G. Katsiaficas \& D. Rose (Eds) The Battle of Seattle: The New Challenge to Capitalist Globalization, pp. 3-20 (New York: Soft Skull Press).

Yuen, E., Katsiaficas, G. \& Rose, D. (Eds) (2001) The Battle of Seattle: The New Challenge to Capitalist Globalization (New York: Soft Skull Press).

Yuen, E. (2004), in: E. Yuen, G. Katsiaficas \& D. Rose (Eds) Confronting Capitalism: Dispatches from a Global Movement (New York: Soft Skull Press).

Douglas Bevington is a doctoral candidate in Sociology at the University of California, Santa Cruz, and is a longtime environmental activist.

Chris Dixon is a graduate student in the History of Consciousness program at the University of California, Santa Cruz. He was a co-founding member of the Direct Action Network for the Seattle WTO protests and he currently works on the administrative collective of Colours of Resistance. 